\title{
Submicron Particles of SBA-15 Modified with MgO as Carriers for Controlled Drug Delivery
}

\author{
Shoucang Shen, * Pui Shan Chow, Fengxi Chen, and Reginald Beng Hee TaN \\ Institute of Chemical and Engineering Sciences; 1 Pesek Road, Jurong Island, Singapore 627833, Republic of Singapore. \\ Received December 12, 2006; accepted April 19, 2007
}

\begin{abstract}
Submicron particles with modified surface were synthesized by a simple one-pot synthesis approach and used as drug carrier for controlled release. Due to the alkalinity of $\mathrm{MgO}$ species on the surface, the amount of a model drug, ibuprofen, adsorbed on the modified surface was increased as compared to pure silica SBA-15 although the surface area was decreased by the surface modification. FTIR investigation indicated that the adsorption state of ibuprofen on MgO modified SBA-15 was different from that on pure silica SBA-15 and pure crystal ibuprofen. The result obtained from in vitro release test exhibited that the surface modification greatly decreased the ibuprofen release rate. In first $6 \mathrm{~h}$ in vitro release test, only $63 \%$ of the adsorbed ibuprofen was released from the $\mathrm{MgO} / \mathrm{SBA}-15(\mathrm{Si} / \mathrm{Mg}=20)$. In contrast, the release of ibuprofen was complete in $1 \mathrm{~h}$ from the pure silica SBA15 under the same release conditions. The surface modified with $\mathrm{MgO}$ created affinity with acidic ibuprofen molecules and retarded the release rate from the mesoporous matrix. In addition, the release rate of ibuprofen could be modulated by varying the content of $\mathrm{MgO}$, and was found to decrease with increasing amount of $\mathrm{MgO}$ on surface of SBA-15 submicron particles.
\end{abstract}

Key words submicron; SBA-15; MgO-modified; controlled release; ibuprofen; drug delivery

Controlled drug delivery technology represents one of the most rapidly advancing areas of biomedical science contributed by chemists and chemical engineers to health care. Controlled delivery systems offer significant advantages over conventional dosage forms, in terms of enhanced efficiency of medicine, and improved patient compliance and convenience over as the efficiency of medicine. The method by which a drug is delivered can have a significant effect on its therapeutic efficacy. The controlled drug release process is attractive and has been widely and intensively studied. Much of this work involves polymers to enable the drug to be delivered at relative constant rate by diffusion control from polymer or polymer composites over time. ${ }^{1-7)}$ The drug is deposited by means of direct compression, coating, wet granulation, or mechanical mixture of both matrix and drug. These methods have in general the disadvantage of non-uniform distribution, which can influence the release rate between different drug compositions. Therefore, much improvement in this field would be expected if chemically homogeneous materials possessing uniformly arranged porosity to accept organic guest molecules are made available.

Novel ordered mesoporous silica materials with biocompatible amorphous pore walls fulfill these requirements and have good potential for biomedical applications of drug delivery and tissue regeneration. ${ }^{8-10)}$ The large pore volume allows high drug loading into the ordered matrix. The large surface area of the internal surface can be modified according to specific purposes for different drugs association on the surface of matrix. Since Vallet-Regi and co-workers ${ }^{11)}$ reported that MCM-41 loaded ibuprofen could be sustained-release in $80 \mathrm{~h}$, mesoporous silica materials have attracted great attention to be a potential controlled drug delivery system. Organic modified MCM-41 with functional groups on the surface could further decrease the delivery rate of ibuprofen. ${ }^{12-15)}$

Among mesoporous materials, SBA-15 possesses a hexagonal array of mesopores $6.0-20 \mathrm{~nm}$ in diameter, which is much larger than the $3.0-\mathrm{nm}$ pores characteristic of the
MCM-41 and MCM-48. Therefore, SBA-15 mesoporous materials could be modified with various surface functional groups and still preserve the large pore channels and surface areas for drug adsorption and desorption. ${ }^{16-19)}$ It is expected to provide greater versatility for the delivery of drug molecules, whereupon the release rate depends to the large extent on the surface properties of drug carrier. The most common morphology of SBA-15 used is noodle-like fiber bundles of several tens of micrometers in length. ${ }^{20)}$ Particle size and morphology are among the significant factors to affect the uptake of formulated drugs through the intestine wall to body fluids for controlled delivery. Thus, it is important to develop mesoporous silica SBA-15 with submicron particle size and having new possibilities for incorporating biological agents within the silica host and for controlling their release kinetics from the matrix. ${ }^{21)}$ In this work, MgO-modified submicron mesoporous silica SBA-15 was prepared by one-pot hydrothermal synthesis route. ${ }^{22)}$ The functionalized surface of the submicron particles with moderate basic properties was used for the controlled release of drug substances using ibuprofen as a model drug with acidic groups.

\section{Experimental}

Synthesis of Materials $\mathrm{MgO}$ modified submicron SBA-15 particles were synthesized by one-pot hydrothermal treatment and in-situ coating process. Typically, $4.0 \mathrm{~g}$ of Pluronic P123 $\left(\mathrm{EO}_{20} \mathrm{PO}_{70} \mathrm{EO}_{20}\right.$, Aldrich) was dissolved in $150.0 \mathrm{~g}$ of $2 \mathrm{~N} \mathrm{HCl}$ solution at $40^{\circ} \mathrm{C}$ under vigorous stirring in $2 \mathrm{~h}$. A certain amount of $\mathrm{Mg}\left(\mathrm{NO}_{3}\right)_{3} \cdot 6 \mathrm{H}_{2} \mathrm{O}$ (Sigma-Aldrich) was introduced to the solution under stirring to form a homogenous solution. Eight and onehalf grams of tetraethyl orthosilicate (TEOS, Sigma-Aldrich) was added and stirred vigorously for $2 \mathrm{~min}$. The mole ratio of components for the mixture is $\mathrm{SiO}_{2}: \mathrm{P} 123: \mathrm{MgO}: \mathrm{HCl}: \mathrm{H}_{2} \mathrm{O}=1.0: 0.016: x(0-0.2): 6.9: 178.6$ where $x$ varies in range of $0-0.2$ corresponding to different loading level of $\mathrm{MgO}$. Then the mixture was kept under static conditions at $40^{\circ} \mathrm{C}$ for $2 \mathrm{~h}$, followed by a hydrothermal treatment at $100^{\circ} \mathrm{C}$ for $24 \mathrm{~h}$. The resulting material was directly evaporated at $100^{\circ} \mathrm{C}$ for $24 \mathrm{~h}$. The material was heated from room temperature to $550^{\circ} \mathrm{C}$ at a heating rate of $2 \% \mathrm{~min}$ and followed by calcinations in air for $6 \mathrm{~h}$.

Drug Loading To load ibuprofen onto $\mathrm{MgO}$ modified SBA-15 materials, $0.8 \mathrm{~g}$ of powder silica SBA- 15 was added to $20 \mathrm{ml}$ of ibuprofen-hexane solution with initial concentration of $40 \mathrm{mg} / \mathrm{ml}$ and adsorption was conducted for $48 \mathrm{~h}$ under stirring at room temperature. The powder was filtered 
and dried at $40^{\circ} \mathrm{C}$ under air flow for $24 \mathrm{~h}$. The amount adsorbed on the samples was measured by thermogravimetric analysis (TGA).

In Vitro Drug Release Studies One-half of drug-loaded material was pressed into a tablet $(13 \times 5 \mathrm{~mm})$ by a pressure of $7.5 \mathrm{MPa}$. The dissolution profile was measured using the standard a USP dissolution tester (VK7010, Varian Co, U.S.A.) operated at $37 \pm 0.1^{\circ} \mathrm{C}$ and stirring rate of $50 \mathrm{rpm}$. Each $0.5 \mathrm{~g}$ tablet was introduced into in the vessel with $500 \mathrm{ml}$ of simulated body fluid (SBF) and drug release kinetic studies were performed. Simulated body fluid (SBF) has a composition very similar to the human plasma (mixed solution of: $136.8 \mathrm{~mm}$ of $\mathrm{NaCl}, 4.2 \mathrm{~mm}$ of $\mathrm{NaHCO}_{3}, 3 \mathrm{~mm}$ of $\mathrm{KCl}, 1.0 \mathrm{~mm}$ of $\mathrm{K}_{2} \mathrm{HPO}_{4} \cdot 3 \mathrm{H}_{2} \mathrm{O}, 1.5 \mathrm{~mm}$ of $\mathrm{MgCl}_{2} \cdot 6 \mathrm{H}_{2} \mathrm{O}, 2.5 \mathrm{~mm}$ of $\mathrm{CaCl}_{2} \cdot \mathrm{H}_{2} \mathrm{O}$ and $0.5 \mathrm{~mm}$ of $\mathrm{Na}_{2} \mathrm{SO}_{4}$ ). The solution was buffered at $\mathrm{pH} 7.4$ with $50 \mathrm{~mm}$ of tri(hydroxymethyl)aminometahane). A sample of the release medium $(3.0 \mathrm{ml})$ was extracted for analysis at regular time intervals using a syringe, and replaced with the same volume of fresh SBF. The drug concentration released into SBF with time was measured by UV-vis spectrophotometer (UV3010 SHIMDZU) at a wavelength of $272 \mathrm{~nm}$. Calculation of the corrected concentration of replaced ibuprofen is based on the following equation: $C_{\text {torr }}=C_{t}+v\left(C_{0}+C_{1} \cdots+C_{t-1}\right) / V$, where $C_{\text {torr }}$ is the corrected concentration at time $t, C_{t}$ is the apparent concentration at time $t, v$ is the volume of sample taken and $V$ is the total volume of the dissolution medium in vessel. ${ }^{23}$ )

Characterization All solid samples were characterized by X-Ray Diffraction (XRD), Scanning Electronic Microscopy (SEM), Fourier Transform Infra Red (FTIR) spectroscopy, The transmission electron microscopic (TEM), and $\mathrm{N}_{2}$ adsorption. X-ray diffraction measurements were performed on a D8-ADVANCE (BRUKER, U.S.A.) X-ray diffractometer in steps of $0.02^{\circ}$ using $\mathrm{Cu} K \alpha$ radiation as X-ray source. The unit cell parameter $\left(a_{0}\right)$ was calculated using the formula $a_{0}=2 d_{100} / \sqrt{3}$, where $d_{100}$ represented the $d$ spacing value of the (100) diffraction peak in XRD patterns of the samples SEM images were taken with a field emission scanning electron microscope (FESEM, JEOL JSM-6700F, JEOL Co., Japan). The framework vibration FTIR spectra were recorded on TFS3000MX (BIO-RAD, Bio-rad Lab. U.S.A.) infrared spectrophotometer at a resolution of $2 \mathrm{~cm}^{-1}$. The samples were thoroughly ground with $\mathrm{KBr}$ pellet before being pressed at 4 ton to form a thin wafer and storage in a desiccator with silica gel desiccant under vacuum for $24 \mathrm{~h}$ prior to measurement. TEM measurement was performed on TECNAI F20 $\left(\mathrm{G}^{2}\right)$ (FEI, Netherlands) electron microscope at $125 \mathrm{kV}$. Nitrogen adsorption/desorption isotherms were measured by using an $\mathrm{Au}$ tosorb-6B gas adsorption analyzer (Quantachrome, U.S.A.) at the temperature of $-196^{\circ} \mathrm{C}$. Before nitrogen adsorption-desorption measurements, each sample was heated at $300^{\circ} \mathrm{C}$ under vacuum for $12 \mathrm{~h}$. The specific surface areas of the samples were determined from the linear portion of the Brumauer-Emmett-Teller (BET) plots. The pore size (diameter $D_{\mathrm{BET}}$ ) distribution was calculated from the adsorption branch of $\mathrm{N}_{2}$ adsorption-desorption isotherms using the conventional Barrett-Joyner-Halenda (BJH) method.

\section{Results and Discussion}

Characterization of MgO Modified SBA-15 Submicron Particles Figure 1 shows the low and high angle XRD patterns of samples of pure silica SBA-15 and SBA-15 in-situ modified with $\mathrm{MgO}$. All samples exhibited typical XRD patterns of SBA-15 mesoporous materials. An intensive diffraction peak observed at $2 \theta=0.84-0.98^{\circ}$ for all samples corresponds to the (100) diffraction peak, accompanying with two small peaks assigned to (110) and (200), is characteristics of ordered structure of 2D hexagonal space group $(p 6 \mathrm{~mm}){ }^{24,25)}$ As compared with pure silica SBA-15, the (100) diffraction for the $\mathrm{MgO}$ modified SBA-15 was shifted to lower angle, resulting in an increase in the corresponding unit cell parameter $a_{0}$. The unit cell parameter $a_{0}$ was $104 \AA$ for pure silica SBA-15 and it was $118 \AA$ for $\mathrm{MgO} / \mathrm{SBA}-15(\mathrm{Si} / \mathrm{Mg}=20)$. When the content of $\mathrm{MgO}$ was increased to $\mathrm{Si} / \mathrm{Mg}=5$, the diffraction peak of (100) shifted to $0.84^{\circ}$ with a unit cell parameter of $121 \AA$. The high angle XRD patterns indicate that the pore wall of all samples of pure silica SBA-15 and $\mathrm{MgO} / \mathrm{SBA}-15$ was in an amorphous state. In addition, for the in-situ modified SBA-15 with $\mathrm{MgO}(\mathrm{Si} / \mathrm{Mg}=20)$, the diffrac-

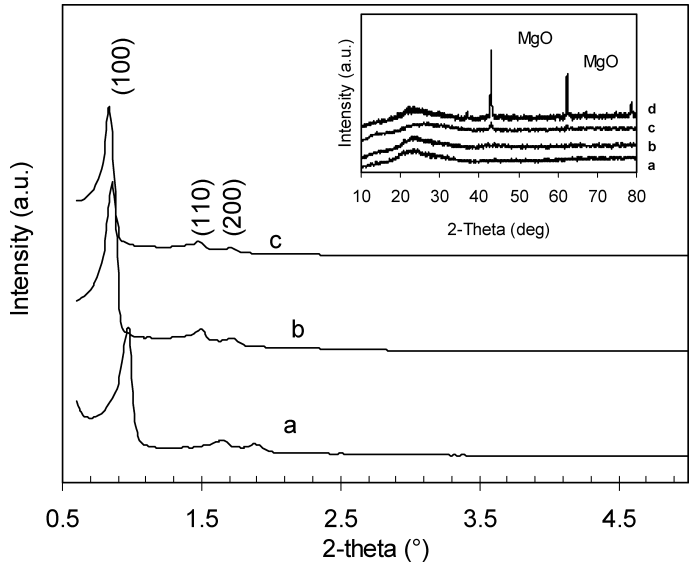

Fig. 1. Low Angle and High Angle (Inset) XRD Patterns of (a) Silica SBA-15 and (b) $\mathrm{MgO} / \mathrm{SBA}-15$ (Si/Mg=20), (c) $\mathrm{MgO} / \mathrm{SBA}-15$ ( $\mathrm{Si} / \mathrm{Mg}=5$ ), (d) $\mathrm{MgO}$ Mixed with Pure Silica SBA-15 $(\mathrm{Si} / \mathrm{Mg}=5)$

tion of $\mathrm{MgO}$ was not observed, indicating that that $\mathrm{MgO}$ was highly dispersed onto the large internal pore surface or embedded in the amorphous pore wall without formation of crystalline $\mathrm{MgO}$. When $\mathrm{MgO} / \mathrm{SBA}-15$ with $\mathrm{MgO}$ content increased to $\mathrm{Si} / \mathrm{Mg}=5$, only a very small diffraction peak appeared at $43^{\circ}$. As compared with $\mathrm{MgO}$ mechanically mixed with pure silica SBA-15, the diffraction peak due to modified $\mathrm{MgO}$ was extremely low although both samples possessed same $\mathrm{MgO}$ content $(\mathrm{Si} / \mathrm{Mg}=5)$. The results suggest that most of the $\mathrm{MgO}$ was coated onto internal surfaces with high dispersion in the amorphous state even with the content as high as $\mathrm{Si} / \mathrm{Mg}=5$.

Figure 2 displays FESEM images of submicron particles of pure silica SBA-15 and MgO modified SBA-15 with different $\mathrm{Si} / \mathrm{Mg}$ ratios. Uniform submicron particles were observed for both samples synthesized by static hydrolysis of TEOS for $2 \mathrm{~h}$ and followed by a hydrothermal treatment of the gel mixture at $100^{\circ} \mathrm{C}$. The average particles size was slightly increased with the presence of $\mathrm{Mg}^{2+}$ in solution mixture during synthesis. For pure silica SBA-15, particle size was $0.5-0.8 \mu \mathrm{m}$ and it was $0.7-0.9 \mu \mathrm{m}$ for the two samples of MgO-modified SBA-15. Nevertheless, the particle size of resultant $\mathrm{MgO}$ modified SBA-15 was well-confined in submicron range and the particles were well dispersed. The surface morphology of submicron mesoporous silica particle was not affected by the presence of $\mathrm{Mg}\left(\mathrm{NO}_{3}\right)_{3}$ in synthesis media. Wei and co-workers ${ }^{22,26)}$ have reported that $\mathrm{MgO}$ could be in-situ coated on to SBA-15 mesoporous materials. By stirring continuously during hydrolysis of TEOS in the strong acidic P123 polymer solution, fiber-like $\mathrm{MgO}$ modified SBA-15 with particle size of $10-100 \mu \mathrm{m}$ was obtained. The stirring condition during the self-assembly process was found to affect the morphology of SBA-15 materials significantly. ${ }^{27)}$ Rod-like particles with length of $1-2-\mu \mathrm{m}$ formed under static hydrolysis and self assembly conditions. ${ }^{21)}$ The monodispersed submicron SBA-15 particles were found to be formed in first $2 \mathrm{~h}$ of static hydrolysis of TEOS and selfassembly of silica species on P123 polymer micelles. ${ }^{28)}$ The subsequent hydrothermal treatment consolidated the pore wall and helped to maintain the uniform mesoporous structure upon calcinations. Although it has been found that the morphology of SBA-15 materials were greatly influenced by 
the inorganic salt in reaction mixtures ${ }^{29,30)}$ in this study, $\mathrm{Mg}\left(\mathrm{NO}_{3}\right)_{3}$ was not found to influence the surface morphology of resulting submicron SBA-15 particle. As the uptake of drug carrier was found to significantly depend on the particle size ${ }^{31)}$ the highly dispersed submicron particle as drug carriers would facilitate the uptake of active pharmaceutical ingredient (API) through oral administration.

Figure 3 shows the transmission electron microscopy (TEM) images of $\mathrm{MgO} / \mathrm{SBA}-15(\mathrm{Si} / \mathrm{Mg}=5)$ submicron particles at different orientations. Figure $3 \mathrm{~A}$ clearly indicates that the hexagonal pores with diameter of $c a .8 \mathrm{~nm}$ are perfectly stacked and Fig. 3B shows the parallel mesoporous channels
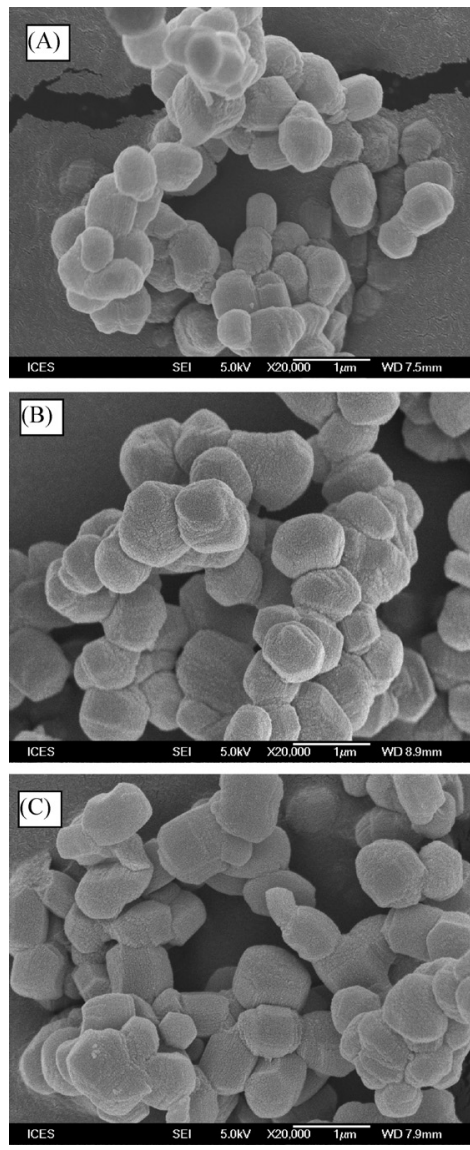

Fig. 2. FESEM Images of (A) Pure Silica SBA-15 and (B) MgO/SBA-15 $(\mathrm{Si} / \mathrm{Mg}=20)$ and $(\mathrm{c}) \mathrm{MgO} / \mathrm{SBA}-15(\mathrm{Si} / \mathrm{Mg}=5)$ Submicron Particles formed in submicron particle.

Figure 4 shows the $\mathrm{N}_{2}$ adsorption-desorption isotherms of pure silica SBA-15 and $\mathrm{MgO} / \mathrm{SBA}-15$ submicron particles. All samples exhibited typical type IV isotherms comprising $\mathrm{H}_{1}$ type hysteresis with parallel adsorption and desorption branches, reflecting the regular array of cylindrical pore structure of SBA-15 materials. ${ }^{32)}$ The amount of $\mathrm{N}_{2}$ adsorption slightly decreased for the $\mathrm{MgO}$-modified submicron SBA-15 $(\mathrm{Si} / \mathrm{Mg}=20)$ compared to the pure silica SBA-15. With the increase of $\mathrm{MgO}$ content, the amount of $\mathrm{N}_{2}$ adsorption decreased. The surface areas were decreased by in-situ coating of $\mathrm{MgO}$ onto the surface of SBA-15 submicron particles. With $\mathrm{Si} / \mathrm{Mg}=20$, the surface areas was slight reduced from 725 to $693 \mathrm{~m}^{2} / \mathrm{g}$ and total pore volume reduced from 1.03 to $1.02 \mathrm{cc} / \mathrm{g}$ as compared to pure silica SBA-15. When the $\mathrm{MgO}$ content increased to $\mathrm{Si} / \mathrm{Mg}=5$, the surface area and pore volume decreased to $596 \mathrm{~m}^{2} / \mathrm{g}$ and $0.87 \mathrm{cc} / \mathrm{g}$, respectively. However, the pore size was not decreased by in-situ coating $\mathrm{MgO}$ onto SBA-15 materials, because the pore size was determined by the size of surfactant micelles in the synthesis media. With the presence of $\mathrm{Mg}\left(\mathrm{NO}_{3}\right)_{3}$ during the selfassembly of silica-surfactant and followed by hydrothermal treatment and direct drying, the resulting pore wall was

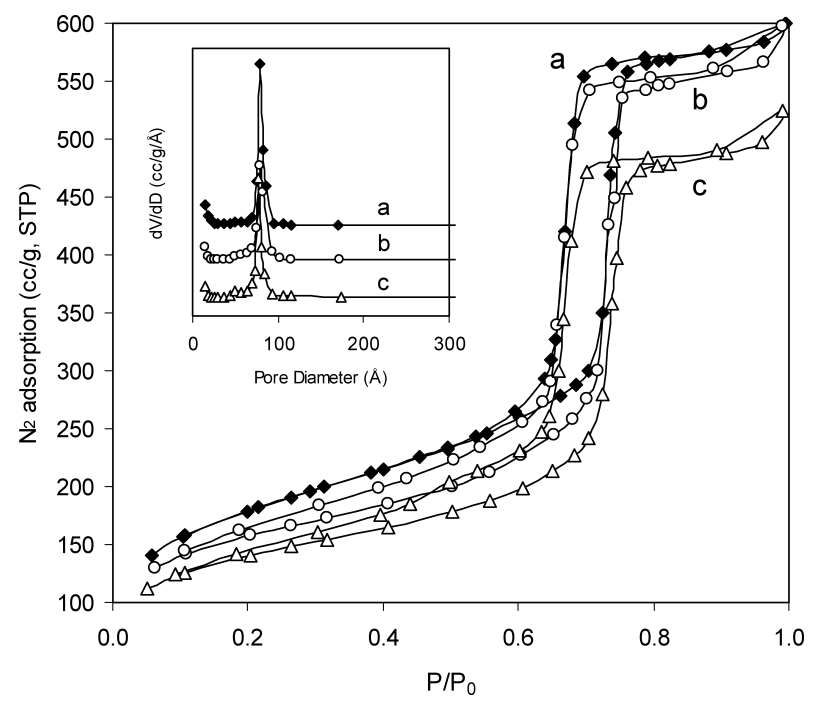

Fig. 4. $\mathrm{N}_{2}$ Adsorption-Desorption Isotherms and Pore Size Distribution of Submicron Particles (a) Pure Silica SBA-15, (b) $\mathrm{MgO} / \mathrm{SBA}-15$ ( $\mathrm{Si} / \mathrm{Mg}=20$ ), and (c) $\mathrm{MgO} / \mathrm{SBA}-15(\mathrm{Si} / \mathrm{Mg}=5)$

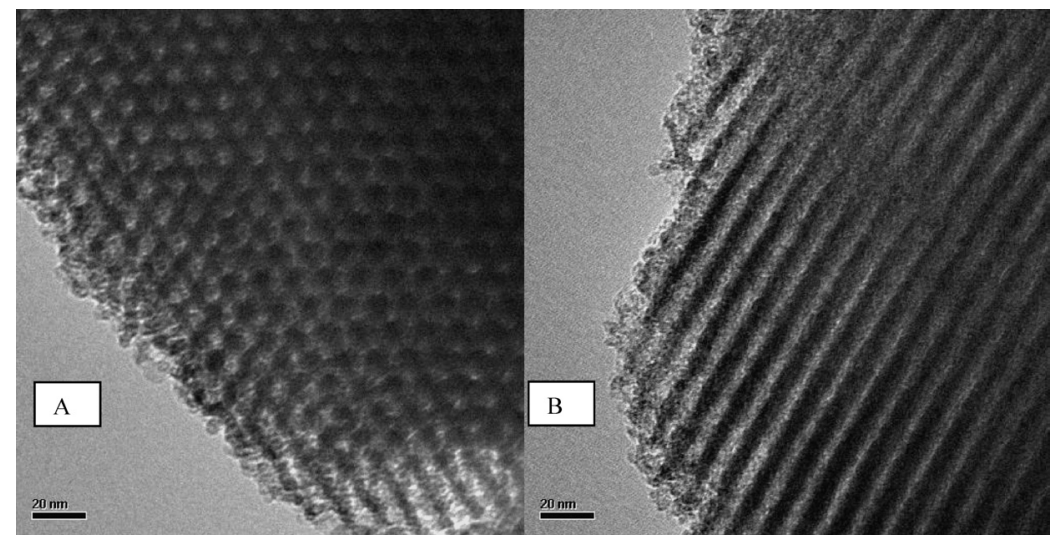

Fig. 3. TEM Images of MgO/SBA-15 ( $\mathrm{Si} / \mathrm{Mg}=5$ ) Submicron Particles: (A) Taken along the Parallel Pore Channels and (B) Taken Vertical to the Parallel Pore Channels 
Table 1. Pore and Surface Properties and Drug Loadings of SBA-15 Submicron Particles Modified with MgO

\begin{tabular}{|c|c|c|c|c|c|}
\hline Sample & $a_{0}(\mathrm{~nm})$ & $D_{\mathrm{BET}}(\mathrm{nm})$ & $S_{\mathrm{BET}}\left(\mathrm{m}^{2} / \mathrm{g}\right)$ & $V_{\mathrm{T}}(\mathrm{cc} / \mathrm{g})$ & $\begin{array}{c}\text { Ibuprofen } \\
\text { loading (wt } \%)\end{array}$ \\
\hline SBA-15 & 10.4 & 7.9 & 725 & 1.03 & 15.8 \\
\hline $\mathrm{MgO} / \mathrm{SBA}-15(\mathrm{Si} / \mathrm{Mg}=20)$ & 11.8 & 8.0 & 693 & 1.02 & 28.6 \\
\hline $\mathrm{MgO} / \mathrm{SBA}-15(\mathrm{Si} / \mathrm{Mg}=5)$ & 12.1 & 8.0 & 569 & 0.87 & 32.2 \\
\hline
\end{tabular}

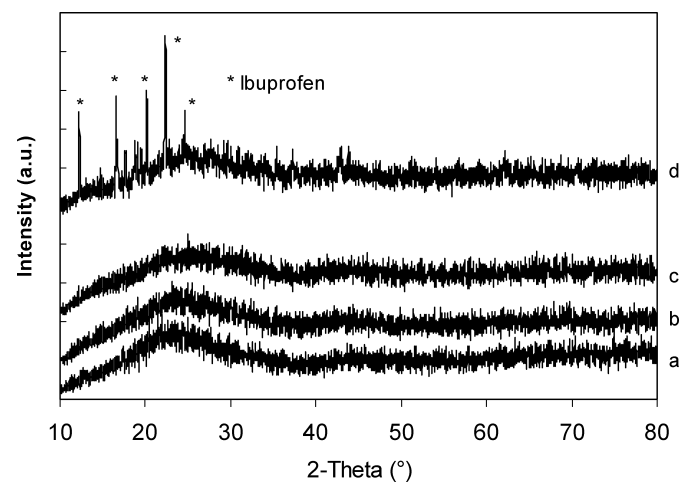

Fig. 5. XRD Patterns of Ibuprofen Loaded on Submicron Particles of (a) Pure Silica SBA-15, (b) $\mathrm{MgO} / \mathrm{SBA}-15$ (Si/Mg=20), (c) $\mathrm{MgO} / \mathrm{SBA}-15$ $(\mathrm{Si} / \mathrm{Mg}=5)$ and (d) $30 \mathrm{wt} \%$ Ibuprofen Mixed with Pure Silica SBA-15

thicker with larger cell parameter. After removal of the soft template surfactant by calcination, the pore size remained constant as the size of the surfactant micelle was not affected by $\mathrm{Mg}^{2+}$ in the solution. Thus the thicker pore wall caused by $\mathrm{MgO}$-coating led to the decrease of surface area and total pore volume of the resultant mesoporous materials.

Drug Loading on MgO-SBA-15 Submicron Particles The drug loading of ibuprofen on SBA-15 and MgO-modified SBA-15 materials is tabulated in Table 1. It is found that drug loading is increased on MgO-modified SBA-15 materials, although the $\mathrm{MgO}$ modified SBA-15 submicron particles have smaller surface area and pore volume. As indicated in Table 1, the loading of ibuprofen on pure silica SBA-15 was only $15.8 \mathrm{wt} \%$; as a comparison, $\mathrm{MgO} / \mathrm{SBA}-15(\mathrm{Si} / \mathrm{Mg}=20)$ submicron particles adsorbed $28.6 \mathrm{wt} \%$ of ibuprofen although its surface area was lower than pure silica SBA-15. With increase of $\mathrm{MgO}$ content to $\mathrm{Si} / \mathrm{Mg}=5$, the ibuprofen loading was increased to $32.2 \%$ due to more adsorption sites created. $\mathrm{MgO}$ is a basic material that is widely used as an alkaline adsorbent and as a catalyst. ${ }^{33-36)} \mathrm{MgO}$ modified SBA15 has been proven to create basic sites on the large surface of SBA-15 materials and significantly improves its adsorption with acidic gases on mesoporous materials. ${ }^{22,26)}$ When ibuprofen was loaded on to mesoporous submicron particles through adsorption from hexane solution, the $\mathrm{MgO}$ modified SBA-15 has higher affinity with acidic drug molecules, thus resulting in higher drug loading.

The adsorbed ibuprofen on SBA-15 materials was found to be in the amorphous state. As shown in Fig. 5, ibuprofen loaded on all SBA-15 submicron particles lacked X-ray diffraction peaks, indicating that no crystallization occurred inside the nanopore channels. Due to the large surface area of SBA-15, ibuprofen was highly dispersed or adsorbed on the surface of SBA-15 when the drug was loaded by adsorption from solution. According to a previous investigation of crystallization processes in confined spaces, crystallization can

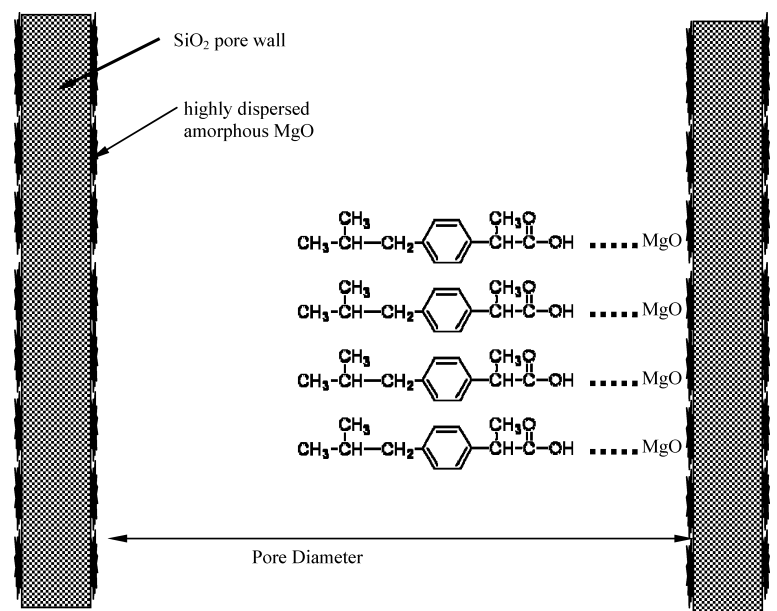

Fig. 6. Illustration of Ibuprofen Molecules Adsorption States on $\mathrm{MgO} / \mathrm{SBA}-15$ Material

only occur in channels with diameter to molecular size ratios above $20 .{ }^{37)}$ The pore diameter in this study was about $8 \mathrm{~nm}$ in this study, which is about 8 to 13 times of the dimension of the ibuprofen molecule (estimated to be $1.0 \times 0.6 \mathrm{~nm}$ ). ${ }^{11)}$ As a comparison in Fig. 5, $30 \mathrm{wt} \%$ of ibuprofen mixed with SBA-15 clearly exhibited the diffraction peaks characteristic for crystals of ibuprofen. The adsorption state of ibuprofen on $\mathrm{MgO} / \mathrm{SBA}-15$ is illustrated in Fig. 6. Ibuprofen molecules were adsorbed on the highly dispersed $\mathrm{MgO}$ on internal surface of modified SBA-15 particles. The affinity of acidic molecules and modifier is believed to retard the drug release from modified drug carrier. For pure silica SBA-15, ibuprofen molecules were weakly and directly attached with surface of silica pore wall.

Figure 7 shows that the FESEM images of ibuprofen loaded SBA-15 and $\mathrm{MgO} / \mathrm{SBA}-15(\mathrm{Si} / \mathrm{Mg}=5)$. The morphology of the submicron particles of SBA-15 was well preserved after drug loading. As the large surface area of SBA-15 mesoporous material is mostly contributed by internal surface area, most of drug molecules adsorbed on the surface of pore channel inside the submicron particles. The outer surface morphology of the resultant ibuprofen loaded SBA-15 was not changed by drug adsorption even though the drug loading was up to $30 \mathrm{wt} \%$.

Drug Release Figure 8 exhibits the percentage of ibuprofen released as a function of time for ibuprofen loaded on pure silica SBA-15 and MgO-modified SBA-15 submicron particles. It was observed that the release was very fast for ibuprofen loaded on pure silica SBA-15 materials, reaching $100 \%$ release in $1 \mathrm{~h}$. This dissolution rate was found to be even faster than that of bulk pure ibuprofen crystal in tablet form, where it needed $5 \mathrm{~h}$ to reach $95 \%$ of dissolution under same dissolution condition. It was also reported that more 


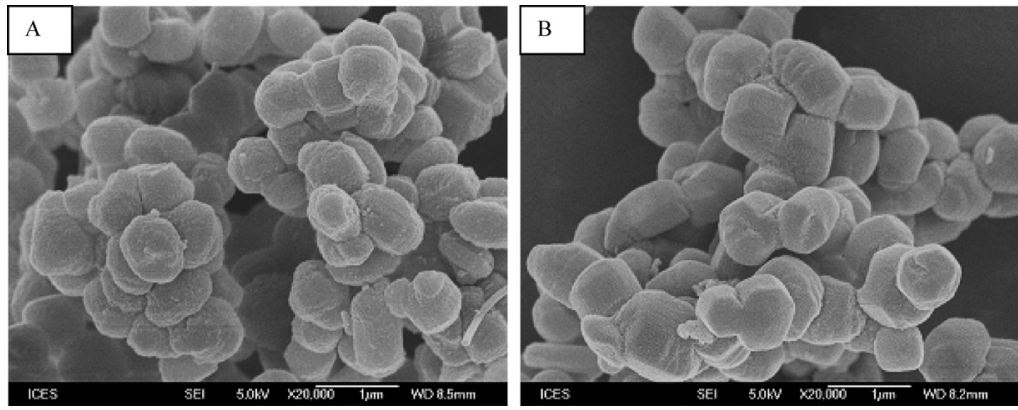

Fig. 7. FESEM Images of Ibuprofen Loaded Submicron Particles of (A) Pure Silica SBA-15 and (B) MgO/SBA-15 (Si/Mg=5)

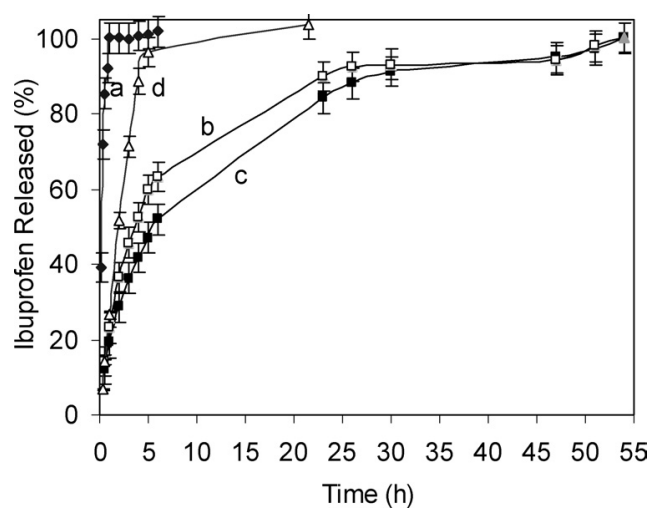

Fig. 8. Cumulative Release Profiles for Ibuprofen Loaded on Submicron Particles of (a) Pure Silica SBA-15, (b) $\mathrm{MgO} / \mathrm{SBA}-15$ (Si/Mg=20), (c) $\mathrm{MgO} / \mathrm{SBA}-15$ (Si/Mg =5); and (d) Pure Ibuprofen Tablet

than $2 \mathrm{~h}$ was needed for complete dissolution. ${ }^{38)}$ The dissolution of amorphous ibuprofen loaded on pure silica SBA-15 is facilitated as compared with pure ibuprofen crystal. This result is greatly different from that of ibuprofen loaded on pure silica MCM-41, ${ }^{11)}$ where it showed a slow controlled release rate although both carriers have large surface areas. The discrepancy could be due to difference in pore size and morphology of drug carriers. In this study, the pore size of SBA15 (ca. $8 \mathrm{~nm})$ was much larger than that of MCM-41 (2$3 \mathrm{~nm}$ ). In addition, the length of the submicron SBA-15 particles used in this study was much shorter than the MCM-41 used in the comparable case. As ibuprofen was finely dispersed on pure silica SBA-15 in the amorphous state and the interaction with the substrate was weak, the large pore size and short pore channel resulted in a faster dissolution rate than pure ibuprofen crystal pellets. However, ibuprofen adsorbed on MgO-modified SBA-15 submicron particles exhibited a much slower release rate. It required more than $50 \mathrm{~h}$ to reach $100 \%$ release of ibuprofen adsorbed. In the first $6 \mathrm{~h}$, $63 \%$ of adsorbed ibuprofen was released from $\mathrm{MgO} / \mathrm{SBA}-15$ $(\mathrm{Si} / \mathrm{Mg}=20)$. With increase of $\mathrm{MgO}$ content, the release rate was further delayed. Only $52 \%$ of ibuprofen was released from $\mathrm{MgO} / \mathrm{SBA}-15(\mathrm{Si} / \mathrm{Mg}=5)$ in the first $6 \mathrm{~h}$. After $6 \mathrm{~h}$, the release rate of ibuprofen decreased noticeably, with a further decrease in rate at around $25 \mathrm{~h}$. The delayed release of ibuprofen from MgO-modified SBA-15 is believed to be attributed to the interaction between ibuprofen molecules and alkaline functional surface. This suggests that the release rate of ibuprofen can be tuned by varying the content of $\mathrm{MgO}$ in $\mathrm{MgO}-$ modified SBA-15 submicron particles.
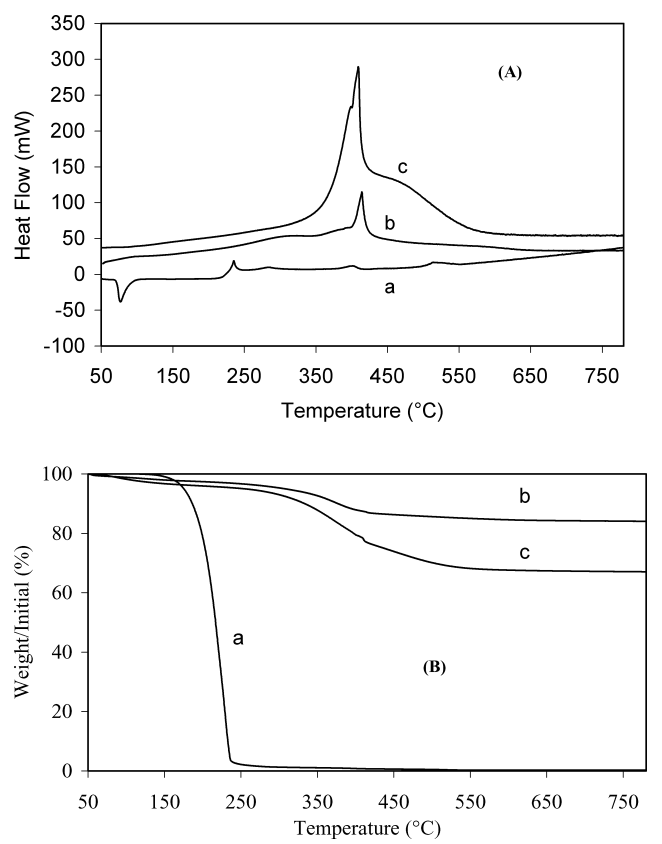

Fig. 9. DSC (A) and TGA (B) Profiles of (a) Pure Ibuprofen Crystal, (b) Ibuprofen Loaded on Pure Silica SBA-15 and (c) Ibuprofen Loaded on $\mathrm{MgO} / \mathrm{SBA}-15(\mathrm{Si} / \mathrm{Mg}=5)$ Submicron Particles

DSC Study on Ibuprofen Loaded Samples Figure 9 depicts the DSC-TGA profiles of ibuprofen loaded on different carriers and as comparison with pure crystal ibuprofen. For pure ibuprofen, an endothermic peak at $78^{\circ} \mathrm{C}$ corresponding to the melting point of crystal ibuprofen was observed. This kind of endothermic peak due to melting of bulk ibuprofen was not detected for ibuprofen adsorbed on the SBA-15 submicron particles as ibuprofen molecules were adsorbed on the large surface in a highly dispersed state. In the temperature range of $300-550^{\circ} \mathrm{C}$, a strong exothermic peak was found for ibuprofen loaded on $\mathrm{MgO} / \mathrm{SBA}-15(\mathrm{Si} / \mathrm{Mg}=5)$ mesoporous material, due to the oxidation of ibuprofen molecules in air. This strong exothermic peak corresponded to the weight loss of ibuprofen in TGA curves (Fig. 9B). As the drug loading on pure silica SBA-15 submicron particle was much lower, the exothermic peak caused by the oxidation of adsorbed ibuprofen was smaller than that on $\mathrm{MgO}$ modified SBA-15. For pure ibuprofen, only a small exothermic peak was observed at the temperature region of $220-250^{\circ} \mathrm{C}$ and the strong exothermic peak at temperature of $300-550^{\circ} \mathrm{C}$ was not appeared. In the Fig. 9B, a quick weight loss at $150-250^{\circ} \mathrm{C}$ for pure ibuprofen was observed, due to the 


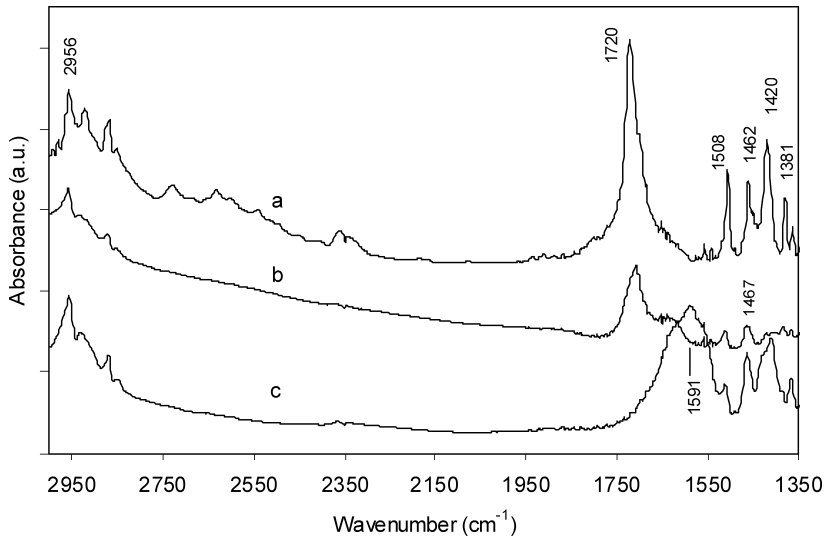

Fig. 10. FTIR Spectra of (a) Pure Ibuprofen Crystal, (b) Ibuprofen Loaded on Pure Silica SBA-15 and (c) Ibuprofen Loaded on MgO/SBA-15 $(\mathrm{Si} / \mathrm{Mg}=5)$

evaporation of ibuprofen. As the melted pure ibuprofen vaporized below the temperature for oxidation reaction, thus exothermic effect was not as strong as that of ibuprofen adsorbed on SBA-15 materials at $300-550^{\circ} \mathrm{C}$. Ibuprofen strongly adsorbed on $\mathrm{MgO} / \mathrm{SBA}-15$ did not evaporate above the boiling point of ibuprofen, and it was oxidized on carriers in the air at the higher temperature range depending on the affinity of molecules and adsorption sites on the surface.

FTIR Investigation on the Interaction of Drug and Carriers FTIR investigation provides the evidence of the interaction of ibuprofen molecule with $\mathrm{MgO}$-modified surface. As shown in Fig. 10, the sample of pure ibuprofen exhibits a strong band at $1720 \mathrm{~cm}^{-1}$, attributed to the $v(\mathrm{C}=\mathrm{O})$ stretching vibration for free ibuprofen molecules. ${ }^{39)}$ The weak bands at 1508 and $1462 \mathrm{~cm}^{-1}$ could be assigned to ring vibrations of the organic molecules. ${ }^{40)}$ Typical $v(\mathrm{CH})$ stretching vibrations of ibuprofen are observed at 2958, 2927, and $2871 \mathrm{~cm}^{-1}$ for pure ibuprofen as well as that loaded on different support. ${ }^{40)}$ For ibuprofen loaded on pure silica SBA-15 submicron particles, the band around $1720 \mathrm{~cm}^{-1}$ still existed. However, for ibuprofen loaded on MgO-modified SBA-15, this characteristic band for carboxyl $\mathrm{C}=\mathrm{O}$ stretching vibration of free ibuprofen was not observed. A new broad band at $1591 \mathrm{~cm}^{-1}$ was detected, which could be due to the partially transfer of proton from the carboxylic acid of ibuprofen to the basic sites of modified surface. It has been reported that, when ibuprofen adsorbed on amino-functional silica mesoporous materials, the band corresponding to $v(\mathrm{C}=\mathrm{O})$ stretching shifted from carboxylic values to the carboxylate value. ${ }^{41,42)} \mathrm{An}$ absorbance band at $1558 \mathrm{~cm}^{-1}$ was found for ibuprofen adsorbed on amino-group grafted SBA-15, and it was assigned to the asymmetric stretching vibration of $\mathrm{COO}^{-} .{ }^{43)}$ In this study, the alkalinity of $\mathrm{MgO}$ modified SBA15 was not as strong as amino groups, the donation of proton from $\mathrm{COOH}$ was not fully accepted as that of amino-functioned surface. Thus, the IR band of $\mathrm{C}=\mathrm{O}$ stretching shifts to $1591 \mathrm{~cm}^{-1}$ for ibuprofen adsorbed on MgO-modified SBA15 submicron particles. These results imply that the alkalinity of pore wall surface play a significant role for adsorption and delivery of acidic drug molecules. The MgO-modified SBA-15 submicron particles apparently have stronger interaction with acidic drug molecules than pure silica SBA-15. FTIR results also indicated the interaction of ibuprofen and pure silica SBA-15 was very weak, thus the release rate of amorphous ibuprofen from pure silica SBA-15 was very fast. The chemical affinity of carboxylic group of ibuprofen with surface basic sites of $\mathrm{Mg} / \mathrm{SBA}-15$ resulted in the controlled release profiles. This application could be expanded to other acidic drug molecules with carboxylic groups.

\section{Conclusion}

The drug carriers of MgO-modified SBA-15 submicron particles synthesized by one-pot in-situ coating route demonstrated a simple, effective approach for well-controlled release of acidic drug molecules. Due to the alkaline $\mathrm{MgO}$ functional surface, the amount of ibuprofen adsorbed on MgO-modified SBA-15 was higher than pure silica SBA-15 although the surface area was decreased by MgO-coating. XRD results indicated that ibuprofen adsorbed on surface of SBA-15 was amorphous. The morphology of SBA-15 submicron particles was well preserved with drug loading up to $30 \mathrm{wt} \%$. The results obtained from in-vitro test exhibited the surface coating of $\mathrm{MgO}$ greatly delayed the ibuprofen release rate, and the release rate was further decreased with increasing the amount of $\mathrm{MgO}$ coated onto the internal surface of SBA-15 submicron particles. Sustained release for time period up to $55 \mathrm{~h}$ could be reached from MgO-modified SBA15 , whereas $100 \%$ ibuprofen could be completed in less than $1 \mathrm{~h}$ from pure silica SBA-15 submicron particle under the same release condition. The delayed release profile from $\mathrm{MgO}$-modified SBA-15 was attributed to the interaction of ibuprofen molecules with drug carrier surface, which was investigated by DSC-TGA and FTIR. TGA-DSC results indicated that adsorbed ibuprofen on SBA-15 desorbed greatly different from the pure ibuprofen crystal. A new FTIR band was observed on ibuprofen adsorbed on $\mathrm{MgO}$-modified SBA-15 due to the proton transfer of ibuprofen to the alkaline functional surface, and the interaction was believed to be contributing factor in the controlled release of ibuprofen from carrier.

\section{References}

1) Davis K. A., Anseth K. S., Critical Rew. Therapeutic Drug Carrier Systems, 19, 385- 423 (2002).

2) Sinha V. R., Bansal K., Kaushik R., Trehan A., Int. J. Pharm., 278, 123 (2004)

3) McHugh A. J., J. Control. Release, 9, 211-221 (2005)

4) Sendil D., Guresel I., Wise D. L., Hasirci V., J. Control Release, 59, 207-217 (1999).

5) Yagmurlu M. F., Korkusuz F., Gursel I., Korkusuz P., Ors U., Hasirci V., J. Biomed. Mater. Res., 46, 494-503 (1999).

6) Wallace D. G., Rosenblatt J., Adv. Drug Deliv. Rev., 55, 1631-1649 (2003).

7) Qiu L. Y., Bae Y. H., Pharm. Res., 23, 1-30 (2006).

8) Vallet-Regi M. A., Ruiz-Gonzalez L., Izquierdo-Barba I., GonzálezCalbet J. M., J. Mater. Chem., 16, 26-31 (2006).

9) Izquierdo-Barba I., Ruiz-González L., Doadrio J. C., González-Calbet J. M., Vallet-Regí M., Solid State Sci., 7, 983-989 (2005).

10) Tozuka Y., Wongmekiat A., Kimura K., Moribe K., Yamamura S., Yamamoto K., Chem. Pharm. Bull., 53, 974-977 (2005).

11) Vallet-Regi M., Ramila A., del Real R. P., Pariente J. P., Chem. Mater., 13, 308-311 (2001).

12) Munoz B., Ramila A., Pariente J. P., Diaz I., Vallet-Regi M., Chem. Mater., 15, 500-503 (2003).

13) Qu F. Y., Zhu G. S., Huang S. Y., Li S. G., Qiu S. L., Chem. Phys. Chem., 7, 400-406 (2006).

14) Tang Q. L., Xu Y., Wu D., Sun Y. H., Wang J. Q., Xu J., Deng F., J. Control. Release, 114, 41-46 (2006).

15) Zeng W., Qian X. F., Zhang Y. B., Yin J., Zhu Z. K., Mater. Res. Bull., 
40, 766-772 (2005).

16) Doadrio J. C., Sousa E. M. B., Izquierdo-Barba I., Doadrio A. L., Perez-Pariente J., Vallet-Regi M., J. Mater. Chem., 16, 462-466 (2006).

17) Xia W., Chang J., J. Control. Release, 110, 522-530 (2006).

18) Doadrio A. L., Sousa E. M. B., Doadrio J. C., Pariente J. P., IzquierdoBarba I., Vallet-Reg M., J. Control. Release, 97, 125-132 (2004).

19) Yang Q., Wang S. H., Fan P. W., Wang L. F., Di Y., Lin K. F., Xiao F. S., Chem. Mater., 17, 5999-6003 (2005).

20) Schmidt-Winkel P., Yang P., Margolese D. I., Chmelka B. F., Stucky G. D., Adv. Mater., 11, 303-307 (1999).

21) Sayari A., Han B. H., Yang Y., J. Am. Chem. Soc., 126, 14348-14349 (2004).

22) Wei Y. L., Wang Y. M., Zhu J. H., Wu Z. Y., Adv. Mater, 15, 19431945 (2003).

23) Fisher K. A., Huddersman K. D., Taylor M. J., Chem. Eur. J., 9, 5873-5878 (2003).

24) Zhao D. Y., Feng J., Huo Q., Melosh N., Fredrickson G. H., Chmelka B. F., Stucky G. D., Science, 279, 548-552 (1998).

25) Zhao D. Y., Huo Q., Feng J., Chmelka B. F., Stucky G. D., J. Am. Chem. Soc., 120, 6024-6036 (1998).

26) Wang Y. M., Wu Z. Y., Wei Y. L., Zhu J. H., Micropor. Mesopor. Mater, 84, 127-136 (2005).

27) Kosuge K., Sato T., Kikukawu N., Takemori M., Chem. Mater, 16, $899-905$ (2004).

28) Shen S. C., Chen F. X., Chow P. S., Phanapavudhikul P., Zhu K. W., Tan R. B. H., Micropor. Mesopor. Mater, 92, 300-308 (2006).

29) Schmidt-Winkel P., Yang P., Margolese D. I., Chmelka B. F., Stucky G.
D., Adv. Mater., 11, 303-307 (1999).

30) Yu C., Fan J., Tian B., Zhao D. Y., Stucky G. D., Adv. Mater, 14 1742-1745 (2002).

31) Jani P., Halbert G. W., Langridge J., Florence A. T., J. Pharm. Pharmacol., 42, 821-826 (1990).

32) Neimark A. V., Ravikovitch P. I., Vishnyakov A., Phys. Rev. E, 62, R1493-1496 (2000)

33) Thomason P., Tyagi O. S., Knözinger H., Appl. Catal. A, 181, 181188 (1999).

34) Lavalley J. C., Catalysis Today 27, 377-401 (1996).

35) Di Cosimo J. I., Díez V. K., Xu M., Iglesia E., Apesteguía C. R., J. Catal., 178, 499-510 (1998).

36) Liu Z., Cortés-concepción J. A., Mustian M., Amiridis M. D., Appl. Catal. A, 302, 232-236 (2006).

37) Sliwinska-Bartkowiak M., Dudziak G., Gras R., Sikorski R., Radhakrishnan R., Gubbins K. E., Colloid Surf. A: Physicochem. Eng. Aspects, 187-188, 523-529 (2001).

38) Costa F. O., Pais A. A. C. C., Sousa J. J. S., Int. J. Pharm., 270, 9-19 (2004).

39) Gordijo C. R., Barbosa C. A. S., Ferreira A. M. D. C., Constantino A. V. R. L., Silva D. D. O., J. Pharm. Sci., 94, 1135-1148 (2005).

40) Andrade A., Namora S. F., Woisky R. G., Wiezel G., Najjar R., Sertié J. A. A., Silva D. D. O., J. Inorg. Biochem., 81, 23-27 (2000).

41) Rámila A., Muñoz B., Pérez-Pariente J., Vallet-Regí M., J. Sol-Gel Sci. Tech., 26, 1199-1202 (2003).

42) Socrates G., "Infrared Characteristic Group Frequencies, Tables and Chatrs," Wily, New York, 1994.

43) Song S. W., Hidajat K., Kawi S., Langmuir, 21, 9568—9575 (2005). 